\title{
Review on bacterial production of alkaline pectinase with special emphasis on Bacillus species
}

\author{
Bijesh Kavuthodi and Denoj Sebastian* \\ Department of Life Sciences, University of Calicut, Kerala, India
}

\begin{abstract}
Pectinases consist of an exclusive group of enzymes which catalyze the degradation of pectic polymers present in the plant cell walls. Today, pectinases are the upcoming industrially important enzyme having major industrial importance and they hold a leading position among the commercially produced industrial enzymes. Microorganisms including yeast, bacteria, actinomycetes and a large number of filamentous fungi are commonly recognized as the best natural sources for the production of pectinase enzyme. The chief source of acidic pectinases is fungi but alkaline pectinases are produced from alkalophilic bacteria, primarily Bacillus spp. The alkaline pectinase has developed as important commercial enzymes with far-flung applications mainly in textile processing, bio-scouring of cotton fibers, degumming and retting of fiber crops, pretreatment of pectic wastewater etc. This review discusses the microbial production of pectinases with special emphasis on bacterial pectinase from Bacillus spp.
\end{abstract}

KEY WORDS: PECTINASE, BACILLUS, POLYGALACTURONASE, PECTATE LYASE, PECTIN LYASE

\section{INTRODUCTION}

Pectinases comprises of a unique group of enzymes which catalyze the degradation of pectic polymers present in the plant cell wall. They belong to the family of polysaccharidases that contribute to the breakdown of pectins from a variety of plants and are also known as pectolytic or pectic enzymes (Prathyusha \& Suneetha, 2011). In the current biotechnological era, pectinase are one of the forthcoming enzymes showing progressive

\section{ARTICLE INFORMATION:}

*Corresponding Author: drds@uoc.ac.in Received $27^{\text {th }}$ Jan, 2018

Accepted after revision $20^{\text {th }}$ March, 2018

BBRC Print ISSN: 0974-6455

Online ISSN: 2321-4007 CODEN: USA BBRCBA

$\therefore$ Thomson Reuters ISI ESC / Clarivate Analytics USA and Crossref Indexed Journal

NAAS Journal Score 2017: 4.38 SJIF 2017: 4.196

- A Society of Science and Nature Publication, Bhopal India 2018. All rights reserved.

Online Contents Available at: http//www.bbrc.in/

DOI: $10.21786 / \mathrm{bbrc} / 11.1 / 4$ increase in their market. They maintained the average annual growth rate of 2.86\% from 27.6 million \$ in 2013 to 30.0 million $\$$ in 2016 and it is estimated that by 2021 , the market size of the pectinase will reach 35.5 million \$ (Global Pectinase Market Research Report, 2017).

The pectinase enzymes are classified based on their mode of action against the galacturonan backbone of pectins. Primarily, there are two groups of pectic enzyme; the de-esterifying enzymes which catalyses the deesterification of pectins and the depolymeriz- 
ing enzymes which break the glycosidic $\alpha-(1-4)$ bonds between GalA residues either by hydrolysis (hydrolases) or by transelimination (lyases). Moreover, the latter two types of enzymes are classified on the basis of whether they exhibit a preferential hydrolytic/transelimination power against pectin, pectic acid or oligogalacturonate as the substrate and whether the pattern of action is random (endo-) or terminal (exo-). Another group of the pectic enzyme is protopectinase (PPase) which convert insoluble native protopectin into soluble pectins (Alkorta et al., 1998; Kashyap et al., 2001; Sharma et al., 2013; Garg et al., 2016; Hassan \&t Ali, 2016). The classifications of pectic enzymes acting on pectic substances are given in Figure 1.

Based on the optimum $\mathrm{pH}$ for enzyme activity, pectic enzymes are also classified into two, acidic and alkaline pectinase. Research and application of acidic pectinase are more established compared with alkaline pectinase. The chief source of acidic pectinase is from fungus Aspergillus niger. Acidic pectinases are used mainly in fruit juice industry for extraction and clarification of fruit juices, improvement of chromaticity and stability of red wines etc. They are also having application in maceration of plant tissue, liquefaction and saccharification of biomass, isolation of protoplasts. Whereas, alkaline pectinase are mostly used in the degumming and retting of fiber crops, textile processing and bio-scouring of cotton fibers, pretreatment of pectic wastewater from fruit juice industries, paper making, coffee and tea fermentation, enzyme based oil extraction etc. The important applications of pectinase are shown in Figure 2. Bacteria, mainly Bacillus spp. are used for the production of alkaline pectinase (Kashyap et al., 2001; Jayani et al., 2005). Information regarding pectinase types, structure, applications, substrate etc. has been reviewed previously by many authors (Alkorta et al., 1998; Kashyap et al., 2001; Hoondal et al., 2002; Jayani et al., 2005; Prathyusha \&t Suneetha, 2011; Sharma et al., 2013; Kohli et al., 2015; Hassan Ct Ali, 2016). This review emphasizes reports on pectinase production by Bacillus spp.

Microbial production of pectinase: It is a well-known fact that, microbes are the prominent source of enzymes because they allow an economical technology with truncated resource consumption and low emission involving no social and political issues, as in the case of animal and plant sources (Chaplin \& Bucke, 1990). It is reported that, fifty percent of accessible enzymes are initiated from fungi and yeast; $35 \%$ from bacteria, while the remaining $15 \%$ are either of plant or animal origin. Filamentous microorganisms are most widely used for pectinase production (Soares et al., 1999). Microbes are chosen as a source of enzyme production compared to plants and animals because; (a) they produce a wide

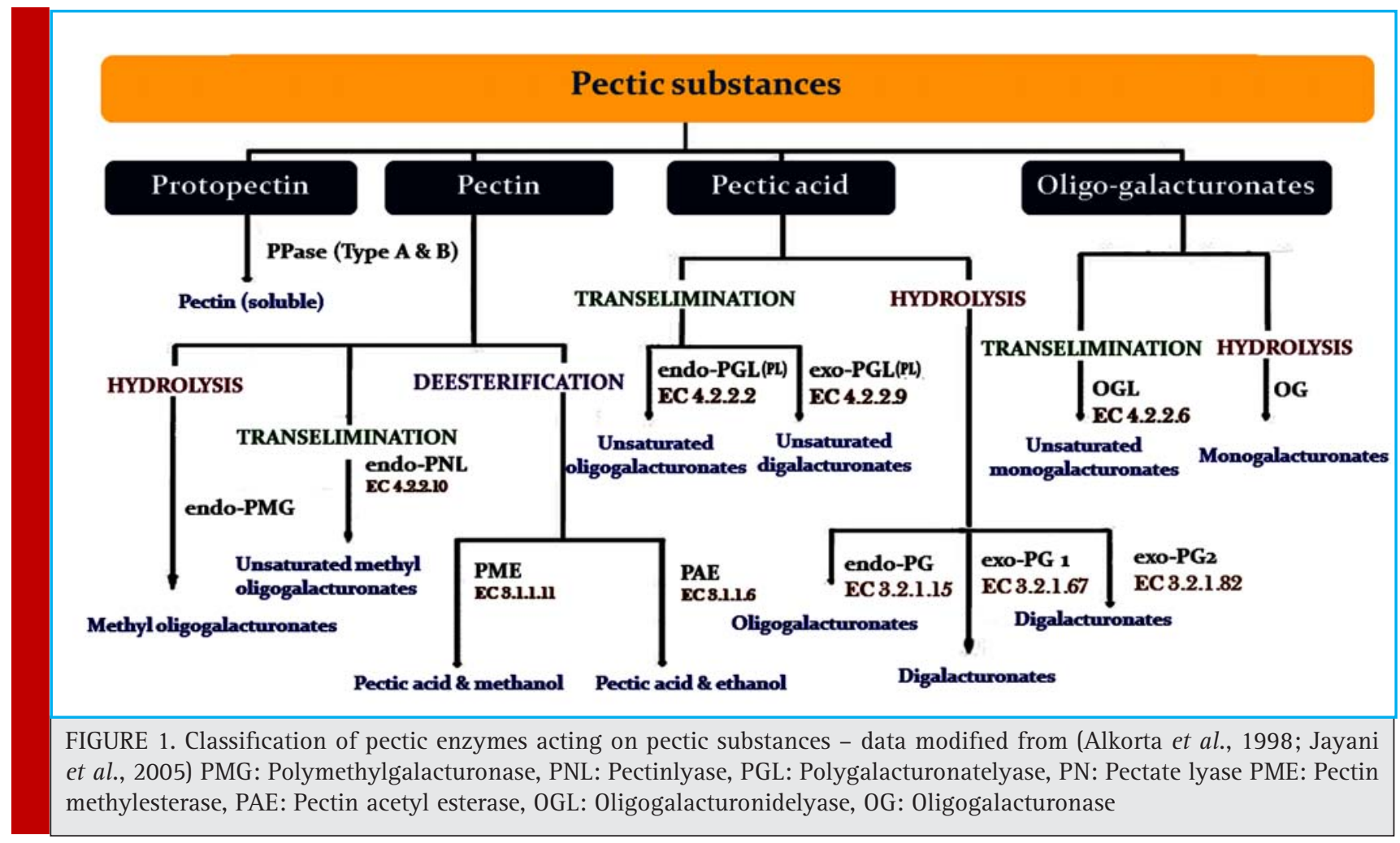




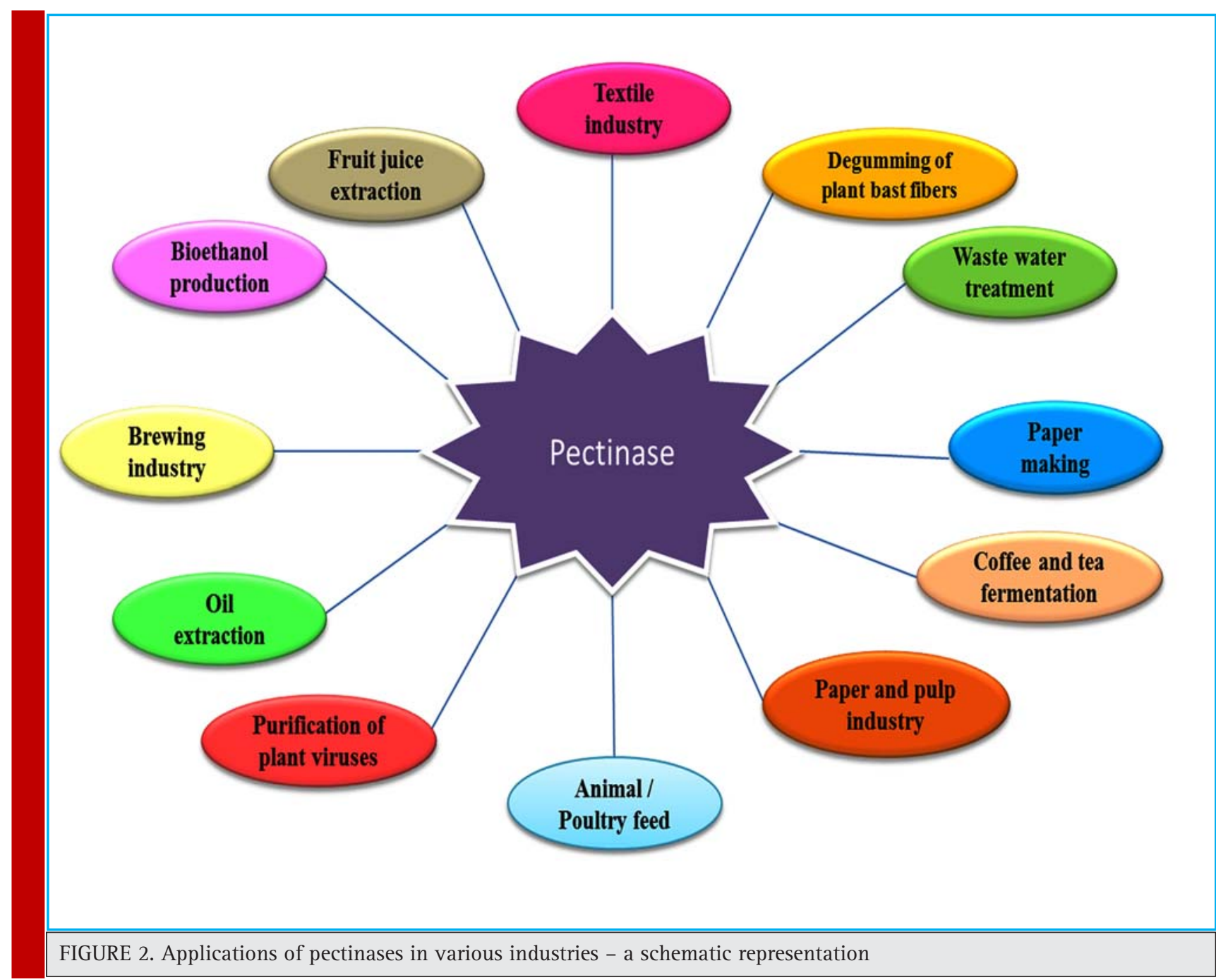

variety of enzymes and their enzyme contents are more predictable and controllable, (b) generally economical in bulk production and dependable provisions for raw material of constant composition, (c) high productivity rate and enzymes obtained via microbial source are greater in volume, (d) microbes are easy to manipulate to derive enzymes of desired nature and they can be cultured in large quantities in a relatively short period of time by the established method of fermentation using sophisticated tools, (e) they can be made to produce enzymes over wide range of environmental condition and (f) plant and animal tissues contain more potentially harmful materials than microbes, including phenolic compounds (from plants), endogenous enzyme inhibitors and proteases (Chaplin \& Bucke, 1990).

The production of pectin degrading enzymes has been extensively reported and meticulously studied in bacteria and filamentous fungi because they play an essential role in the phytopathogenesis (Blanco et al., 1999). Several reports are available regarding pectinase enzymes by the microorganism such as bacteria, fungi, yeast and actinomycetes. They are also distributed in higher plants and in some protozoa, nematodes and insects but they are not found in higher animals (Jayani et al., 2005; Pedrolli et al., 2009; Sharma et al., 2013).

Pectinase production by fungi: Filamentous fungi have been used for more than 50 years in the production of industrial enzymes (Dalboge, 1997). Many extracellular enzymes are produced by fungi which are capable of decomposing organic matter and one such enzyme is pectinolytic enzymes. Filamentous fungi are considered as one of the most potent producers of pectinases and they can be employed extensively in SSF for the economic production process. Various types of fungal species have been reported to be employed for the production of pectinases. Aspergillus niger is the most commonly used fungal species for industrial production of pectinolytic enzymes (Gummadi \& Panda, 2003). Findings on the isolation, characterization, selection, properties and fermen- 
tation of $A$. niger strains for the production of pectinolytic enzymes using different substrates was made by different workers (Finkler et al., 2017). Other species of Aspergillus were also reported to produce pectinase including $A$. oryzae A. fumigatus, A. terreus, A. soje, A. awamori etc (Pedrolli et al., 2009; Garg et al., 2016). Production of endo-PGL was firstly reported in A. giganteus (Pedrolli Et Carmona, 2014). Further, species of Penicillium, Fusarium, Mucor, Neurospora crassa, Sclerotinia sclerotiorum etc also have role in pectinase production (Pedrolli et al., 2009; Pedrolli \&t Carmona, 2014; Garg et al., 2016). The fungus produces these enzymes to break down the middle lamella in plants so that it can extract nutrients from the plant tissues and insert fungal hyphae.

Pectic enzyme production in yeasts: The pectinolytic enzyme production in yeasts has received less consideration and only a few yeast species show this ability (Blanco et al., 1999). The first reports of pectinolytic (endo-PG) production by yeasts were described by Luh and Phaff in 1951 in Saccharomyces fragilis. Among different yeast species representing all yeast genera, they found that only six (S. fragilis, S. fragilis var. no. 351, S. thermantitonum, Torulopsis kefyr, Candida pseudotropicalis var. lactosa, and Candida pseudotropicalis) were capable of causing a noticeable change in pectin (Luh \& Phaff, 1951). Recent reports are also added to describe the ability of Yeast species for pectinase production these includes; Saccharomyces sp., Cryptococcus sp., Aureobasidium pullulans, Rhodotorula dairenensis, Kluyveromyces marxianus, Geotrichum klebahnii, Wickerhanomyces anomalus etc. (Alimardani Theuil et al., 2011; Merin et al., 2015; Hassan Et Ali, 2016; Naumov et al., 2016).

Bacterial production of pectinase: A review of the currently available literature reveals little quantitative information about the diversity of bacterial genera having pectinolytic properties. Bacterial pectinase is produced mainly by bacteria belonging to genera Bacillus and Erwinia. Elyrod in 1942 reported that the bacterium Erwinia sp. can degrade pectin with the aid of pectin degrading enzymes (Elrod, 1942) and in the past decade, bacterial pectinase biosynthesis has been extensively studied in phytopathogens, especially in the soft-rotting Erwinia species E. carotovora and E. chrysanthemi which are reported to produce a set of pectinolytic enzymes such as PL, PG, PME, and PAE (Matsumoto et al., 2003).

Chessen et al., 1980 reviewed that bacteria like Bacillus, Pseudomonas and Micrococcus isolated from retting flax, jute, sisal and coir, and Erwinia from coffee fruits have shown to possess the ability to degrade pectin by producing pectinolytic enzymes (Chesson, 1980). Other bacterial genera reported to have pectinolytic properties include species of Pseudomonas (Sohail Et Latif, 2016),
Streptomyces (Ramirez-Tapias et al., 2015) Lactobacillus (Karam \&t Belarbi, 1995) etc.

Importance of bacterial production of pectinase: Aspergillus niger, a GRAS microorganism is the major organism used for the industrial production of pectinase. However, this mold also secretes several other enzymes which may trigger collateral reactions such as the release of volatile phenols less desirable for the production of wine or fruit juices, for instance arabinofuranosidase, which can cause turbidity (Whitaker, 1990). Pectinases from fungal sources are produced best under acidic $\mathrm{pH}$ and low temperature conditions and can therefore not be used in various industrial bioprocesses which utilize neutral to alkaline $\mathrm{pH}$ with high temperatures exceeding $45^{\circ} \mathrm{C}$. It has been shown that bacteria produce pectinase that withstands high $\mathrm{pH}$ and temperature (Hoondal et al., 2002; Andrade et al., 2011). Also, it is easy to harvest pectinase than fungus as it is an extracellular product in bacterial culture (Sohail \& Latif, 2016). Bacterial strains producing commercial enzymes are always preferred over fungal strains because of ease of fermentation process (for production) and implementation of strain improvement techniques or any modern technique to increase the production yield (Prathyusha \&t Suneetha, 2011). Moreover, bacterial pectinases with novel properties have the added advantage that enzyme production is achieved in less time as compared to fungal sources (Joshi et al., 2015).

Bacillus species for industrial enzyme production: Among the diverse types of microorganisms inhabiting in the soil, bacteria are the amplest and major organism. Considering the bacterial genera of soil, Bacilli are most abundant followed by Cocci and Spirilla. The genus Bacillus and Cocci comprises several varieties of industrially important species contributing approximately half of the existing commercial production of bulk enzymes (Priest, 1977; Aaisha \&t Barate, 2016). Bacillus species have been the imperative industrial enzyme producers with roles in applied microbiology for over a millennium.

Because of several reasons Bacillus species continue to be the predominant bacterial workhorses in microbial fermentations (Schallmey et al., 2004; Satyanarayana.T et al., 2005). They produce more than two dozen of biologically active molecules generating a high potential for biotechnological and biopharmaceutical applications (Stein, 2005). Also, it is estimated that enzymes from Bacillus spp. makeup about $50 \%$ of the total enzyme market (Schallmey et al., 2004). Another major feature that makes these groups predominant is that most of them are environmental friendly, don't have fastidious nutritional requirements and are easy to grow and handle (Sohail \&t Latif, 2016). Bacillus species such as $B$. subtilis and B. licheniformis are on the Food and Drug 
Administration's GRAS (generally regarded as safe) status (Food and Drug Administration, 1999; Schallmey et al., 2004). Moreover, the biochemistry, physiology, and genetics of $B$. subtilis and other species are well studied and the complete genome sequence of $B$. subtilis 168 comprising of 4100 protein-coding genes has been published in 1997 (Kunst et al., 1997).

Various properties of Bacillus strains are reported which make them superior in industrial biotechnology, including their high growth rates leading to short fermentation cycle times, ability to secrete proteins into the extracellular medium (Acton, 2012; Barros et al., 2013) and their ability to adapt with changing environmental and nutritional conditions (Buescher et al., 2012; Nicolas et al., 2012). The capacity of selected Bacillus strains to produce and secrete large quantities (20-25 g/L) of extracellular enzymes has placed them among the most important industrial enzyme producers (Satyanarayana. et al., 2005). Moreover, many researchers used strains belonging to Bacillus, because this genus includes strains (such as B. subtilis) that can grow on cheap substrates such as agro-wastes (Sakai et al., 1989).

Pectinase production by Bacillus spp.: Pectic enzymes are of functional relevance in the retting process and evidence regarding pectinolytic properties of Bacillus spp. was recorded years ago. Different species of the genus Bacillus have been reported to be retting agents and active against pectic materials (Potter \& McCoy, 1955). Nortje and Vaughn, 1953 tested the pectinolytic activity of B. subtilis and B. pumilus in relation to the softening of olives and pickles (Nortje \&t Vaughn, 1953). The first in vitro fermentation studies of pectin and pectic acid was reported in 1955 using B. polymyxa strain 30 (Potter \& McCoy, 1955). Over the past few years, pectinolytic properties have been described in several Bacillus species.

It is evident from many research works that, among different bacterial isolates screened for pectinolytic properties Bacillus strains were selected as the most potent enzyme producers (Soares et al., 1999; Jayani et al., 2010; Rehman et al., 2012; Kavuthodi et al., 2015; Sohail \&t Latif, 2016). As mentioned in the introduction, alkaline pectinases have a wide variety of industrial applications and, bacteria mainly Bacillus spp. are the chief producers. Apart from this fact, there are also some other reasons for researchers to focus on pectinase from Bacillus spp. These include; (i) they produce all class of pectic enzymes, (ii) have short fermentation period for enzyme production, (iii) can produce enzymes very economically by using different agro-wastes as cheap substrates, (iv) fermentation can be attained by either SSF, Smf and (v) genetic information regarding pectinase genes of many Bacillus spp. are available in various nucleotide sequence databases. Thus it supports successful cloning and expression of pectinase gene in other organisms.

Pectic enzymes from Bacillus sp.: Bacillus spp. are renowned producers of all classes of pectinases including hydrolases, lyases, esterases and protopectinases. The important strains of Bacillus reported for different groups of pectinases are listed under;

Hydrolases: The pectic hydrolases are a type of depolymerases that split the $\alpha$-(1,4)-glycosidic bonds between galacturonic monomers by hydrolytic cleavage releasing mono-, di-, oligo galacturonates. These enzymes have been divided into four groups; those acts on pectate were called polygalacturonases (PG), while those preferentially hydrolyze pectin were called polymethylgalacturonases (PMG). In connection with their mode of action on the galacturonic acid backbone, the prefixes endo- and exo- used (Alkorta et al., 1998). It is a member of glycosyl-hydrolases family 28 (Pedrolli et al., 2009). These are one of the most studied and widely used pectinases which has high potential in commercial applications especially in fruit juice industry.

Bacillus strains are inferred to be the potent sources of exo-PG (Nagel \&t Vaughn, 1961; Kobayashi et al., 2001; Jahan et al., 2017). The ability of B.polymyxa in PG production was reported in 1961 (Nagel \&t Vaughn, 1961). A number of Bacillus species including B. subtilis, $B$. pumilus and $B$. licheniformis were reported to have PG production ability. A novel, alkaline and thermostable PG produced from an environmental isolate Bacillus sp. MG-cp-2 was reported by Kapoor et al., in 2000 and its application in degumming of ramie and sunn hemp bast fibres was also revealed in the next year (Kapoor et al., 2000; Kapoor et al., 2001). Further, the ability of this isolate to produce PG by both SmF and SSF was also confirmed (Kapoor \& Kuhad, 2002). Reports regarding a high molecular weight (115000 Da) alkaline exo-PG in a culture of Bacillus sp. strain KSM-P576 was publicized in 2001(Kobayashi et al., 2001). The ability of B. sphaericus for PG production was initially reported by Jayani et al., 2010 (Jayani et al., 2010).

Among several bacterial strains isolated from soil and rotten vegetables, the strain which produced maximum PG was identified as B. licheniformis KIBGE IB-2 (Rehman et al., 2012). Also, the PG produced from this isolate was immobilized in chitosan for continuous degradation of pectin polymers (Rehman et al., 2014). Further, properties of the enzyme were characterized and reported that the $P G$ is having thermal stability and is able to perform its catalytic activity in a diversified environment (Rehman et al., 2015). Pectinolytic (PG) properties of a new soil isolate $B$. subtilis C4 was reported in 2014 by Kusuma and reddy (Kusuma \&t Reddy, 2014a). Further, after purification and characterization of the enzyme, 
they suggested that there was a threefold increase in the specific activity of PG produced by this isolate (Kusuma \& Reddy, 2014b). PMG activity from Bacillus sp. strain BR1390, a novel environmental isolate was presented in the same year (Rastegari \&t Karbalaei, 2014).

Bacillus spp. were also reported for endo PG production. Endo-PG, exo-PG and PNL activities of five Bacillus strains isolated from decaying vegetable material was studied by Sores et al., 2001 and these enzymatic solutions resulted in maximal reduction of the solution of citrus pectin viscosity, between 80 and $97 \%$ (Soares et al., 2001). The molecular weight of endo-PG produced by B.subtilis was found around the range of $67 \mathrm{kDa}$ (Munir \&t Haidri, 2015).

Lyases/trans-eliminases: Lyases or trans-eliminases cleave $\alpha(1,4)$-glycosidic linkages by transelimination resulting in galacturonide with a double bond between C-4 and C-5 at the non-reducing end. They split the glycosidic bonds of either pectate (endo- and exopolygalacturonate lyase -PGL) or pectin (polymethylgalacturonate lyase - PMGL). Up to the recent times, all described pectin lyases were endo-PGL (Alkorta et al., 1998). The first report of an exo-pectin lyase was in 2014, in the fungus A. giganteus (Pedrolli \&t Carmona, 2014). But the enzyme has not yet been reported in Bacillus sp. These enzymes are classified into the polysaccharide lyase family 1 (CAZy database). PGL has an absolute requirement of $\mathrm{Ca} 2+$ ions whereas PMGL requires $\mathrm{Ca} 2+$ and other cations only for its stimulation (Jayani et al., 2005).

Production, applications, biochemical and molecular characteristics of lyases acting on pectic polymers have been reviewed previously (Dubey et al., 2016). Kelly and Fogarty, 1978 reported PL production from an isolated soil bacterium Bacillus sp. RK9 and noted that hydrolysis of substrate occurred in a random fashion and the enzyme was 50\% more active towards acid soluble pectic acid than towards sodium polypectate (Kelly \& Fogarty, 1978). B. stearothermophilus with pectinolytic activity has been isolated by Karbassi and Vaughn, 1980 and found that it is producing a considerable amount of endo-polygalacturonic acid trans-eliminase (endoPATE) (Karbassi \&t Vaughn, 1980). They also noted that enzyme produced by this organism was much more heat stable than previously reported similar enzymes from the mesophilic B. polymyxa (Nagel \&t Vaughn, 1961) and the thermotolerant B. pumilus (Dave et al., 1976).

Details regarding a bacterial strain (Bacillus sp. PN33) producing large amounts of extracellular PNL was revealed in 1998 where, the maximum activity was found at acidic $\mathrm{pH}$ of 6 and is an unusual example for bacterial PNL (Kim et al., 1998). Another high yielding pectinase strain, Bacillus sp. DT7 producing alkalothermophilic PNL with a shorter incubation period of
$24 \mathrm{hr}$ was reported in 2000 (Kashyap et al., 2000). A low-molecular-weight (20,300 Da), high-alkaline PL was found in an alkaline culture of Bacillus sp. strain KSMP15 by Kobayashi et al., 1999 and suggested that this may be a novel enzyme that belongs to a new family (Kobayashi et al., 1999). Later, it was also reported that the strain KSM-P15 produces high alkaline PL with high molecular weight (70,000 Da) (Ogawa et al., 2000).

A thermophilic bacterial strain of Bacillus sp. with endo-PL activity has been isolated by Tako et al., 2000 and noted that it had PPase activity, besides PL activity on lemon protopectin and cotton fibers (Takao et al., 2000). A novel alkalophilic strain of B. pumilus BK2 producing a new type of extracellular endo- PL with high $\mathrm{pI}$ and a high $\mathrm{pH}$ optimum was reported in 2006 (Klug-Santner et al., 2006). The PL producing ability tested from a group of six Bacillus species (B. subtilis, B. pumilus, B. sphaericus, B. cereus, B. thuringiensis, and $B$. fusiformis) isolated from cocoa fermentation, it was revealed that $B$. fusiformis, B. subtilis, and B. pumilus species were the best PL producers compared to other species (Ouattara et al., 2011).

Esterases: The major component of pectic polysaccharides is homogalacturonan (HG), constituting about 65\% of the pectin and contains $(1 \rightarrow 4)$ linked $\alpha$-D-galacturonic acids (1,4-d-GalpA) which can be acetylated or methyl esterified, called smooth regions of pectin. The group pectin esterases comprises of pectin methylesterase (PME) and pectin acetyl esterase (PAE). The enzyme PME catalyzes reactions according to the double-displacement mechanism and its types, mode of action, structure etc. were reviewed previously (Kohli et al., 2015) whereas PAE hydrolyzes the acetyl ester from the HG region of pectin forming pectic acid and acetate (Remoroza et al., 2014). These enzymes act before the action of PG and PL which need non-esterified substrates (Kashyap et al., 2001). These are a well-studied group of enzymes, which belong to carbohydrate esterase (CE) family 8 of CAZy database (Remoroza et al., 2015).

The PME gene of E. crysanthemi B374 was successfully cloned in B. subtilis in 1991 (Heikinheimo et al., 1991) and its purification and characterization were also reported (Pitkanen et al., 1992). A recombinant acetylesterase from B. licheniformis DSM13 was purified and biochemically characterized by Remoroza et al., 2014 and reported to deacetylates a wide range of acetyl-rich pectins (Remoroza et al., 2014). Later they also reported PME from the same organism that de-methylesterifies lemon pectin and sugar beet pectin in a stepwise manner (Remoroza et al., 2015).

Protopectinases: Bacillus sp. was also reported to produce PPase, an enzyme that liberates water-soluble pec- 
tic substances by restricted hydrolysis from water-insoluble protopectin in plant cell walls (Sakai et al., 1989; Sakai \&t Sakamoto, 1990; Sakamoto et al., 1994; Takao et al., 2000). There are two types of protopetinases based on their reaction mechanism; A-type and B-type. A-type PPases react reacts with the polygalacturonic acid region of protopectin (inner site) and the B-type PPases react with the polysaccharide chains that may connect the polygalacturonic acid chain and cell wall constituents (outer site) (Sakai et al., 1993). A-type PPases are again classified in to PPase-F, -L and -S based on the organism they isolated and all these types are having an approximate molecular weight of $30 \mathrm{kDa}$. B-type PPases are also in different types such as PPase- B, -C and -T. PPase-B, $-C$ and $-T$ have molecular weights of 45,30 , and $55 \mathrm{kDa}$, respectively. PPase- $\mathrm{B}$ and $-\mathrm{C}$ have an isoelectric point (pI) of around 9.0 whereas PPase-T has a pI of 8.1 (Gundala \&t Chinthala, 2017).

Saki et al., (1989) used some strains belonging to the genus Bacillus such as; B. subtilis, B. amyloliquefaciens, B. cereus, B. circulans, B. coagulans, B. firmus, $B$. licheniformis, B. macerans, and B. pumilus, to study the production of PPase and concluded that B.subtilis IF0 12113 produce a new type of 'PPase -B' in respect to its reaction mechanism of the solubilization of protopectin, since it does not catalyze the degradation of polygalacturonic acid (Sakai et al., 1989). Further, they also reported 'PPase-C' (does not react with rabbit antiserum against PPase -B) from B. subtilis IF0 3134, (Sakai Et Sakamoto, 1990). Later, from the culture filtrate of B.subtilis IF0 3134 Sakamoto et al., 1994 discovered two pectinolytic enzymes PPase-N and PPase-R. But, according to their substrate specificities and modes of action, these could be respectively classified as endo-PL and endo - PNL (Sakamoto et al., 1994).

The major strains of Bacillus spp. that has been reported recently for pectinase production with their characteristic temperature and $\mathrm{pH}$ are shown in Table 1.

Shorter fermentation period for enzyme production: The time required for the production of pectinase by Bacillus spp. are remarkably less when compared to other microbial pectinases reported in the literature (Kashyap et al., 2000). Literature review indicates that maximum pectinase production through many strains of Bacillus can be attained within $48 \mathrm{~h}$ of fermentation period. The optimum condition for pectinase production by $B$. firmus was recorded at a fermentation time for $18 \mathrm{~h}$ and the enzyme production was declined after 30 h (Roosdiana et al., 2013). Whereas, pectinase production by $B$. subtilis SS started after $18 \mathrm{~h}$ of incubation and the production reached highest at $24 \mathrm{~h}$ (Ahlawat et al., 2009). Alkaline pectinase production by $B$. subtilis WSHB04-02 showed an optimum fermentation time of
$25 \mathrm{~h}$ (Wang et al., 2007). Maximum pectinase production by B. pumilus desr1 was attained in $30 \mathrm{~h}$ through $\mathrm{SmF}$ using fermenter (Sharma \& Satyanarayana, 2006) while enzyme production by $B$. gibsonii S-2 reached highest in $48 \mathrm{~h}\left(\right.$ at $35^{\circ} \mathrm{C}$ ) through SSF (Li et al., 2005).

Economical enzyme production utilizing agro-wastes as substrates: Pectinase production from Bacillus spp. can be also achieved economically by utilizing different agro-waste as substrate. It is proved that orange peel waste can be used as a sole carbon source for pectinase production by various strains of Bacillus (Kapoor et al., 2000; Embaby et al., 2014; Tepe \& Dursun, 2014; Kaur \&t Gupta, 2017). Wheat bran is another substrate, proven as a cheap and easily available source throughout the year for higher pectinase production and many researchers used wheat bran as an economical carbon source for pectinase production by Bacillus spp. Among various agro-byproducts studied for PG production by Bacillus sp. MG-cp-2, it is found that PG production level was boosted significantly by using wheat bran and ramie fibre in the production media (Kapoor et al., 2000). Bacillus strains cultivated on wheat bran produced endo-PG, exo-PG and PNL in the crude enzymatic solution (Soares et al., 2001). A high yield of pectinase (PG) was attained from $B$. licheniformis KIBGE IB-21 (Rehman et al., 2012) and B. licheniformis KIBEIB3 using wheat bran as substrate (Jahan et al., 2017). Various other agro-industrial wastes such as; rice bran, cassava bagasse, sugar beet pulp, carrot peels etc. are also exploited for pectinase production by Bacillus spp. (Ghazala et al., 2015; Nawawi et al., 2017).

Mode of fermentation by either SmF or SSF: Pectinase production using Bacillus sp. can be attained by either SSF, SmF or by both. High quantities of PG is produced by Bacillus strains cultivated by SmF and semi-SSF (Soares et al., 1999). Multiple pectinase enzymes activities such as endo-PG, exo-PG and PNL was showed by SSF culture filtrate of Bacillus strains (Soares et al., 2001). Improved PG from Bacillus sp.MG-cp-2 under SmF and SSF and effect of amino acids and their analogues, vitamins and surfactants in fermentation was reported in 2002 (Kapoor Et Kuhad, 2002). Medium optimization was found to effective in both SSF and Smf for pectinase production using Bacillus strains (Ghazala et al., 2015; Bibi et al., 2016; Kaur \& Gupta, 2017). Zou et al., 2014 developed a new Fed-Batch fermentation for enhanced production of alkaline PGL using $B$. subtilis 7-3-3. The process combines the enzymatic pretreatment of the carbon source with controlled $\mathrm{pH}$ of the fermentative broth to enhance enzyme production in a cheap manner (Zou et al., 2014).

Cloning and expression of pectinase gene: Genetic information regarding pectinase genes of many Bacillus 


\begin{tabular}{|c|c|c|c|c|c|}
\hline \multirow[t]{2}{*}{ No. } & \multirow[t]{2}{*}{ Bacillus species } & \multirow{2}{*}{\begin{tabular}{|l} 
Type of \\
pectinase
\end{tabular}} & \multicolumn{2}{|c|}{ Characteristics } & \multirow[b]{2}{*}{ References } \\
\hline & & & $\mathrm{pH}$ & Temp $\left({ }^{\circ} \mathrm{C}\right)$ & \\
\hline \multirow[b]{2}{*}{1} & \multirow[b]{2}{*}{ B. subtilis } & Pectinase & 8.0 & 50 & (Torimiro \&t Okonji, 2013) \\
\hline & & Endo -PG & 5 & 60 & (Munir \&t Haidri, 2015) \\
\hline 2 & B. subtilis KSM-P358 & Exo-PG & 8 & 55 & (Sawada et al., 2001) \\
\hline 3 & B. subtilis EFRL 01 & PG & 8 & 45 & (Qureshi et al., 2012) \\
\hline 4 & B. subtilis (TCCC11286) & PL & 9 & 50 & (Liu et al., 2012) \\
\hline 5 & B. subtilis 168 & PL & 9.5 & 50 & (Zhang et al., 2013) \\
\hline 6 & B. subtilis C4 & PG & 9 & 60 & (Kusuma \&t Reddy, 2014b) \\
\hline 7 & B. subtilis 7-3-3 & PGL & 6.5 & 34 & (Zou et al., 2014) \\
\hline 8 & B .subtilis BKDS1 & PG, PNL,PL & 8 & 40 & (Kavuthodi et al., 2015) \\
\hline 9 & B. subtilis AD11 & Pectinase & 8.42 & 30 & (Nawawi et al., 2017) \\
\hline 10 & B. subtilis SAV-21 & Pectinase, PNL & & & (Kaur \&t Gupta, 2017) \\
\hline 11 & B.subtilis Btk27 & Pectinase & 7.5 & 50 & (Oumer \& Abate, 2017) \\
\hline 12 & Bacillus sp. N16-5 & PL & 11.5 & 50 & (Li et al., 2010) \\
\hline 13 & Bacillus sp. SMIA-2 & & 10 & $60-70$ & (Andrade et al., 2011) \\
\hline 14 & Bacillus sp. strain BR1390 & PMG & 6 & 60 & (Rastegari \& Karbalaei, 2014) \\
\hline 15 & Bacillus sp. ZGL14 & pectinase & 8.6 & 50 & (Yu et al., 2017) \\
\hline 16 & Bacillus sp ZJ1407 & pectinase & 5 & 37 & (Yu \&t Xu, 2018) \\
\hline 17 & B. pumilus (NRRL B-212) & Exo-pectinase & 8 & 30 & (Tepe \& Dursun, 2014) \\
\hline 18 & B. pumilus & Exo-pectinase & 8 & 30 & (Tepe \& Dursun, 2014) \\
\hline 19 & B. pumilus (ATCC 7061) & PL & 8 & 65 & (Liang et al., 2015) \\
\hline \multirow[t]{2}{*}{20} & \multirow[t]{2}{*}{ B. licheniformis KIBGE IB-21 } & \multirow[t]{2}{*}{ PG } & 7 & 37 & (Rehman et al., 2012) \\
\hline & & & $8-10$ & 45 & (Rehman et al., 2015) \\
\hline 21 & B. licheniformis SHG 10 & PG & 8 & 37.8 & (Embaby et al., 2014) \\
\hline \multirow[t]{2}{*}{22} & \multirow[t]{2}{*}{ B. licheniformis DSM-13 } & PAE & 8 & 50 & (Remoroza et al., 2014) \\
\hline & & PME & 8 & 50 & (Remoroza et al., 2015) \\
\hline 23 & B. licheniformis KIBGE IB-3 & PG & 7 & 37 & (Jahan et al., 2017) \\
\hline 24 & B. stearothermophilus & Pectinase & 7.5 & 60 & (Torimiro \& Okonji, 2013) \\
\hline 25 & B. cereus & Pectinase & 8.5 & 37 & (Namasivayam et al., 2011) \\
\hline 26 & B. cereus & Pectinase & 8 & 50 & (Torimiro \&t Okonji, 2013) \\
\hline 27 & B. sphaericus (MTCC 7542) & PG & 6.8 & 30 & (Jayani et al., 2010) \\
\hline 28 & B. megaterium $A K 2$ & PL & 8.5 & 50 & (Mukhopadhyay et al., 2012) \\
\hline 29 & B. clausii & PNL & 10 & 60 & (Li et al., 2012) \\
\hline 30 & B. firmus & PG & 7 & 50 & (Roosdiana et al., 2013) \\
\hline 31 & B. halodurans M29 & Pectinase & 10 & 80 & (Mei et al., 2013) \\
\hline 32 & B. tequilensis SV11 & PL & 9 & 60 & (Chiliveri \&t Linga, 2014) \\
\hline 33 & B. mojavensis I4 & Pectinase & 8 & 60 & (Ghazala et al., 2015) \\
\hline 34 & B. vallismortis (JQ990307) & PG & & & (Sohail \&t Latif, 2016) \\
\hline
\end{tabular}

spp. are available in various nucleotide sequence databases. Thus it supports successful cloning and expression of pectinase gene in other organisms. The most cloned pectinase gene from Bacillus sp. is PL gene 'pel'. The first cloning and characterization of a pel gene from the Bucillus genus was reported in B.subtilis. The cloned gene indicated a 1,260 bp open reading frame (ORF) encoding a 420 amino acid polypeptide which includes a 21 amino acid (aa) signal sequence. Molecular weight is found to be $45,605 \mathrm{Da}$ and the purified enzyme had similar properties to the PL isolated from extracellular media of the organism (Nasser et al., 1993). Since 
then many researchers reported the successful cloning, expression, sequencing and characterization of pectinase genes (especially PL) from several Bacillus strains (Li et al., 2010; Dubey et al., 2016).

The gene encoding the PNL of B. subtilis IFO 3134, has been cloned, sequenced, and characterized in 1996 and it consists of a coding sequence of 345 aa and expression of the PNL in E.coli was also reported (Sakamoto et al., 1996). The gene encoding the exo-PG (pehK) of Bacillus isolate was cloned and characterized in 2001. The cloned gene revealed a 2940 ORF consist of 980 aa (signal sequence -27 aa and mature protein -953 aa) (Sawada et al., 2001). A highly alkaline thermostable pectinase from B. halodurans M29 was cloned and expressed in E.coli. The expressed enzyme showed high thermostability and long half-life and only $54 \%$ sequence similarity to known enzymes and thus considered novel (Mei et al., 2013). The gene encoding Bacillus PAE was also cloned and expressed in E. coli (Bolvig et al., 2003; Remoroza et al., 2014).

\section{PRESENT SCENARIO}

The reports on pectinase production by Bacillus spp. are still continuing with latest findings. Kavuthodi et al., 2015 isolated and identified the most potent pectinolytic bacterial strain as B.subtilis BKDS1 and found to produce pectinases (PG, PL \& PNL) also, coproduction of biosurfactant along with pectinase was reported (Kavuthodi et al., 2015). Pectinase production by $B$. mojavensis I4 using carrot peels and its application in sesame seeds oil extraction was reported in 2016 (Ghazala et al., 2015). In the same year, it was reported that among different microbial species screened for pectinase production, most prominent pectinase producing isolates were Bacillus sp. and identified as $B$. firmus, B. coagulans, B. endophyticus and B. vietnamensis (Aaisha \&t Barate, 2016). Extracellular pectinase production and its purification from a new strain of isolated B.subtilis were also published in 2016 (Mercimek Takcı \&t Turkmen, 2016).

The results of a recent study indicated that out of 20 isolates screened for xylanopectinolytic enzyme activity, the most prominent strain was identified as $B$. subtilis ADI1 (Nawawi et al., 2017). Also, pectinolytic enzyme production by $B$. subtilis SAV-21 was also reported in 2017 (Kaur \&t Gupta, 2017). The study conducted by Jahan et al., in 2017 revealed that B. licheniformis KIBGE IB-3 has potential to produce a high amount of pectinase by utilizing different agro-wastes (Jahan et al., 2017). Thermo acidic pectinase production from Bacillus sp. ZJ1407 has a good acidic and thermal stability within a pH range of $3.0-5.0$ and at $80-90{ }^{\circ} \mathrm{C}(\mathrm{Yu}$ \&t $\mathrm{Xu}, 2018)$.

\section{CONCLUSION}

As revealed in this review, Bacillus spp. are highly eff1cient for pectinase production mainly by alkaline pectinase and upholds their position as dominant pectinase producer among bacterial genera. They have proved to produce almost all classes of pectinase enzymes based on the substrate provided. It is quite evident from the literature that $B$. subtilis is the leading bacterium reported to have pectinolytic property followed by B. pumilus. So, considering the importance of alkaline pectinase, new bacterial strains especially from the genus Bacillus need to be identified for the industrial production of pectinase.

Conflict of Interests: There are no conflicts of interest.

\section{REFERENCES}

Aaisha, G., \& Barate, D. (2016) Isolation and identification of pectinolytic bacteria from soil samples of Akola region, India. Int J Curr Microbiol App Sci, 5: 514-521.

Acton, Q. A. (2012). Advances in Bacillaceae Research and Application: 2011 Edition: ScholarlyEditions.

Ahlawat, S., Dhiman, S. S., Battan, B., Mandhan, R. P., \&t Sharma, J. (2009) Pectinase production by Bacillus subtilis and its potential application in biopreparation of cotton and micropoly fabric. Process Biochem, 44(5): 521-526.

Alimardani Theuil, P., Gainvors Claisse, A., \& Duchiron, F. (2011) Yeasts: An attractive source of pectinases-From gene expression to potential applications: A review. Process Biochem, 46(8): 1525-1537.

Alkorta, I., Garbisu, C., Llama, M. J., \& Serra, J. L. (1998) Industrial applications of pectic enzymes: a review. Process Biochem, 33(1): 21-28.

Andrade, M. V. V. d., Delatorre, A. B., Ladeira, S. A., \&t Martins, M. L. L. (2011) Production and partial characterization of alkaline polygalacturonase secreted by thermophilic Bacillus sp. SMIA-2 under submerged culture using pectin and corn steep liquor. Food Sci Technol (Campinas), 31(1): 204-208.

Barros, F. F., Simiqueli, A. P., de Andrade, C. J., \&t Pastore, G. M. (2013) Production of enzymes from Agroindustrial wastes by Biosurfactant producing strains of Bacillus subtilis. Biotechnol Res Int, 2013: 103960.

Bibi, N., Ali, S., \&t Tabassum, R. (2016) Statistical Optimization of Pectinase Biosynthesis from Orange Peel by Bacillus licheniformis Using Submerged Fermentation. Waste biomass valor, 7(3): 467-481.

Blanco, P., Sieiro, C., \& Villa, T. G. (1999) Production of pectic enzymes in yeasts. FEMS Microbiol Lett, 175(1): 1-9.

Bolvig, P. U., Pauly, M., Orfila, C., Scheller, H. V., \& Schnorr, K. (2003). Sequence analysis and characterisation of a novel pectin acetyl esterase from Bacillus subtilis Advances in pectin and pectinase research (pp. 315-330): Springer.

Buescher, J. M., Liebermeister, W., Jules, M., Uhr, M., Muntel, J., et al. (2012) Global network reorganization during 
dynamic adaptations of Bacillus subtilis metabolism. Science, 335(6072): 1099-1103.

Chaplin, M. F., \&t Bucke, C. (1990). Sources of enzymes Enzyme Technology. UK: Cambridge University Press.

Chesson, A. (1980) A Review: Maceration in Relation to the Post-harvest Handling and Processing of Plant Material. J Appl Bacteriol, 48(1): 1-45.

Chiliveri, S. R., \&t Linga, V. R. (2014) A novel thermostable, alkaline pectate lyase from Bacillus tequilensis SV11 with potential in textile industry. Carbohydr Polym, 111: 264272.

Dalboge, H. (1997) Expression cloning of fungal enzyme genes; a novel approach for efficient isolation of enzyme genes of industrial relevance. FEMS Microbiol Rev, 21(1): 2942.

Dave, B. A., Vaughn, R. H., \& Patel, I. B. (1976) Preparation, separation and degradation of oligouronides produced by the polygalacturonic acid transeliminase of Bacillus pumilus. J Chromatogr, 116(2): 395-405.

Dubey, A. K., Yadav, S., Kumar, M., An, G., \&t Yadav, D. (2016) Molecular Biology of Microbial Pectate Lyase: A Review. Br Biotechnol J, 13(1).

Elrod, R. P. (1942) The Erwinia-Coliform Relationship. J Bacteriol, 44(4): 433-440.

Embaby, A. M., Masoud, A. A., Marey, H. S., Shaban, N. Z., \& Ghonaim, T. M. (2014) Raw agro-industrial orange peel waste as a low cost effective inducer for alkaline polygalacturonase production from Bacillus licheniformis SHG10. Springerplus, 3: 327.

Food and Drug Adminisreation (1999). Carbohydrase and protease enzyme preparations derived from Bacillus subtilis or Bacillus amyloliquefaciens; Affirmation of GRAS Status as direct food ingredients. Retrieved from https://federalregister. gov/a/99-10011

Finkler, A. T. J., Biz, A., Pitol, L. O., Medina, B. S., Luithardt, H., et al. (2017) Intermittent agitation contributes to uniformity across the bed during pectinase production by Aspergillus niger grown in solid-state fermentation in a pilot-scale packed-bed bioreactor. Biochem Eng J, 121: 1-12.

Garg, G., Singh, A., Kaur, A., Singh, R., Kaur, J., et al. (2016) Microbial pectinases: an ecofriendly tool of nature for industries. 3 Biotech, 6(1): 47.

Ghazala, I., Sayari, N., Romdhane, M. B., Ellouz-Chaabouni, S., \&t Haddar, A. (2015) Assessment of pectinase production by Bacillus mojavensis I4 using an economical substrate and its potential application in oil sesame extraction. J Food Sci Technol, 52(12): 7710-7722.

Global Pectinase Market Research Report (2017). http://www. marketresearchstore.com/report/global-pectinase-marketresearch-report 2017-190713

Gummadi, S. N., \&t Panda, T. (2003) Purification and biochemical properties of microbial pectinases - a review. Process Biochem, 38(7): 987-996.
Gundala, P. B., Et Chinthala, P. (2017). Extremophilic Pectinases, Extremophilic Enzymatic Processing of Lignocellulosic Feedstocks to Bioenergy (pp. 155-180): Springer.

Hassan, B., Et Ali, S. (2016) A Review on Biotechnological impact of Pectinases in Industries. JPCBS, 1(2): 1-6.

Heikinheimo, R., Hemila, H., Pakkanen, R., \&t Palva, I. (1991) Production of pectin methylesterase from Erwinia chrysanthemi B374 in Bacillus subtilis. Appl Microbiol Biotechnol, 35(1): 51-55.

Hoondal, G. S., Tiwari, R. P., Tewari, R., Dahiya, N., \& Beg, Q. K. (2002) Microbial alkaline pectinases and their industrial applications: a review. Appl Microbiol Biotechnol, 59(4-5):409-418.

Jahan, N., Shahid, F., Aman, A., Mujahid, T. Y., \&t Qader, S. A. U. (2017) Utilization of agro waste pectin for the production of industrially important polygalacturonase. Heliyon, 3(6): e00330.

Jayani, R. S., Saxena, S., \&t Gupta, R. (2005) Microbial pectinolytic enzymes: A review. Process Biochem, 40(9): 2931-2944.

Jayani, R. S., Shukla, S. K., \&t Gupta, R. (2010) Screening of Bacterial Strains for Polygalacturonase Activity: Its Production by Bacillus sphaericus (MTCC 7542). Enzyme Res, 2010: 306785.

Joshi, M., Nerurkar, M., \&t Adivarekar, R. (2015) Characterization, kinetic, and thermodynamic studies of marine pectinase from Bacillus subtilis. Prep Biochem Biotechnol, 45(3): 205220.

Kapoor, M., Beg, Q. K., Bhushan, B., Dadhich, K. S., \&t Hoondal, G. S. (2000) Production and partial purification and characterization of a thermo-alkali stable polygalacturonase from Bacillus sp MG-cp-2. Process Biochem, 36(5): 467-473.

Kapoor, M., Beg, Q. K., Bhushan, B., Singh, K., Dadhich, K. S., et al. (2001) Application of an alkaline and thermostable polygalacturonase from Bacillus sp MG-cp-2 in degumming of ramie (Boehmeria nivea) and sunn hemp (Crotalaria juncea) bast fibres. Process Biochem, 36(8-9): 803-807.

Kapoor, M., \& Kuhad, R. C. (2002) Improved polygalacturonase production from Bacillus sp. MG-cp-2 under submerged (SmF) and solid state (SSF) fermentation. Lett Appl Microbiol, 34(5): 317-322.

Karam, N. E., \& Belarbi, A. (1995) Detection of polygalacturonases and pectin esterases in lactic acid bacteria. World $\mathrm{J}$ Microbiol Biotechnol, 11(5): 559-563.

Karbassi, A., \&t Vaughn, R. H. (1980) Purification and properties of polygalacturonic acid trans-eliminase from Bacillus stearothermophilus. Can J Microbiol, 26(3): 377-384.

Kashyap, D. R., Chandra, S., Kaul, A., \& Tewari, R. (2000) Production, purification and characterization of pectinase from a Bacillus sp DT7. World J Microbiol Biotechnol, 16(3): 277-282.

Kashyap, D. R., Vohra, P. K., Chopra, S., \&t Tewari, R. (2001) Applications of pectinases in the commercial sector: a review. Bioresour Technol, 77(3): 215-227.

Kaur, S. J., \& Gupta, V. K. (2017) Production of pectinolytic enzymes pectinase and pectin lyase by Bacillus subtilis SAV-21 
in solid state fermentation. Annals of Microbiol, 67(4): 333342.

Kavuthodi, B., Thomas, S. K., \&t Sebastian, D. (2015) Co-production of Pectinase and Biosurfactant by the Newly Isolated Strain Bacillus subtilis BKDS1. Br Microbiol Res J, 10(2).

Kelly, C. T., \&t Fogarty, W. M. (1978) Production and properties of polygalacturonate lyase by an alkalophilic microorganism Bacillus sp. RK9. Can J Microbiol, 24(10): 1164-1172.

Kim, J. C., Kim, H. Y., \& Choi, Y. J. (1998) Production and characterization of acid-stable pectin lyase from Bacillus sp. PN33. J Microbiol Biotechnol, 8(4): 353-360.

Klug-Santner, B. G., Schnitzhofer, W., Vrsanska, M., Weber, J., Agrawal, P. B., et al. (2006) Purification and characterization of a new bioscouring pectate lyase from Bacillus pumilus BK2. J Biotechnol, 121(3): 390-401.

Kobayashi, T., Higaki, N., Suzumatsu, A., Sawada, K., Hagihara, H., et al. (2001) Purification and properties of a highmolecular-weight, alkaline exopolygalacturonase from a strain of Bacillus. Enzyme Microb Technol, 29(1): 70-75.

Kobayashi, T., Koike, K., Yoshimatsu, T., Higaki, N., Suzumatsu, A., et al. (1999) Purification and properties of a low-molecular-weight, high-alkaline pectate lyase from an alkaliphilic strain of Bacillus. Biosci Biotechnol Biochem, 63(1): 65-72.

Kohli, P., Kalia, M., \&t Gupta, R. (2015) Pectin methylesterases: A review. J Bioprocess Biotech, 5(5): 1.

Kunst, F., Ogasawara, N., Moszer, I., Albertini, A. M., Alloni, G., et al. (1997) The complete genome sequence of the gram-positive bacterium Bacillus subtilis. Nature, 390(6657): 249-256.

Kusuma, M., \&t Reddy, D. S. R. (2014a) Optimization of Polygalacturonase using isolated Bacillus subtilis $\mathrm{C} 4$ by submerged fermentation. J Pharm Res, 8(2): 106-112.

Kusuma, M., \&t Reddy, D. S. R. (2014b) Purification and Characterization of Polygalacturonase using Isolated Bacillus subtilis C4. Res J Microbiol, 9(2): 95.

Li, G., Rao, L., Xue, Y., Zhou, C., Zhang, Y., et al. (2010) Cloning, expression, and characterization of a highly active alkaline pectate lyase from alkaliphilic Bacillus sp. N16-5. J Microbiol Biotechnol, 20(4): 670-677.

Li, Z. M., Bai, Z. H., Zhang, B. G., Li, B. J., Jin, B., et al. (2012) Purification and Characterization of Alkaline Pectin Lyase from a Newly Isolated Bacillus clausii and Its Application in Elicitation of Plant Disease Resistance. Appl Biochem Biotechnol, 167(8): 2241-2256.

Li, Z. M., Bai, Z. H., Zhang, B. G., Xie, H. J., Hu, Q. B., et al. (2005) Newly isolated Bacillus gibsonii S-2 capable of using sugar beet pulp for alkaline pectinase production. World J Microbiol Biotechnol, 21(8-9): 1483-1486.

Liang, C., Gui, X., Zhou, C., Xue, Y., Ma, Y., et al. (2015) Improving the thermoactivity and thermostability of pectate lyase from Bacillus pumilus for ramie degumming. Appl microbiol biotechnol, 99(6): 2673-2682.

Liu, Y., Chen, G., Wang, J., Hao, Y., Li, M., et al. (2012) Efficient expression of an alkaline pectate lyase gene from Bacillus sub- tilis and the characterization of the recombinant protein. Biotechnol Lett, 34(1): 109-115.

Luh, B. S., \&t Phaff, H. J. (1951) Studies on polygalacturonase of certain yeasts. Arch Biochem Biophys, 33(2): 212-227.

Matsumoto, H., Jitareerat, P., Baba, Y., \&t Tsuyumu, S. (2003) Comparative study of regulatory mechanisms for pectinase production by Erwinia carotovora subsp. carotovora and Erwinia chrysanthemi. Molecular plant-microbe interactions, 16(3): 226-237.

Mei, Y., Chen, Y., Zhai, R., \&t Liu, Y. (2013) Cloning, purification and biochemical properties of a thermostable pectinase from Bacillus halodurans M29. J Mol Catal B Enzym, 94: 77-81.

Mercimek Takc1, H. A., \&t Turkmen, F. U. (2016) Extracellular pectinase production and purification from a newly isolated Bacillus subtilis strain. Int J Food Prop, 19(11): 2443-2450.

Merin, M. G., Martin, M. C., Rantsiou, K., Cocolin, L., \&t de Ambrosini, V. I. M. (2015) Characterization of pectinase activity for enology from yeasts occurring in Argentine Bonarda grape. Braz J Microbiol, 46(3): 815-823.

Mukhopadhyay, A., Dasgupta, A. K., Chattopadhyay, D., \& Chakrabarti, K. (2012) Improvement of thermostability and activity of pectate lyase in the presence of hydroxyapatite nanoparticles. Bioresour Technol, 116: 348-354.

Munir, N., \&t Haidri, S. (2015) Production, Purification and Characterization of Endopolygalacturonase by Bacillus subtillus. Biochem Anal Biochem, 2015.

Nagel, C. W., \&t Vaughn, R. H. (1961) The characteristics of a polygalacturonase produced by Bacillus polymyxa. Arch Biochem Biophys, 93(2): 344-352.

Namasivayam, E., Ravindar, J., Mariappan, K., Akhil, J., Mukesh, K., et al. (2011) Production of extracellular pectinase by Bacillus cereus isolated from market solid waste. J Bioanal Biomed, 3: 070-075.

Nasser, W., Awade, A. C., Reverchon, S., \&t Robert Baudouy, J. (1993) Pectate lyase from Bacillus subtilis: molecular characterization of the gene, and properties of the cloned enzyme. FEBS Lett, 335(3): 319-326.

Naumov, G. I., Shalamitskiy, M. Y., \&t Naumova, E. S. (2016) New family of pectinase genes PGU1b-PGU3b of the pectinolytic yeast Saccharomyces bayanus var. uvarum. Dokl Biochem Biophys, 467(1): 89-91.

Nawawi, M. H., Mohamad, R., Tahir, P. M., \&t Saad, W. Z. (2017) Extracellular Xylanopectinolytic Enzymes by Bacillus subtilis ADI1 from EFB's Compost. Int Sch Res Notices, 2017: 7831954

Nicolas, P., Mader, U., Dervyn, E., Rochat, T., Leduc, A., et al. (2012) Condition-dependent transcriptome reveals high-level regulatory architecture in Bacillus subtilis. Science, 335(6072): 1103-1106.

Nortje, B. K., \&t Vaughn, R. H. (1953) The pectolytic activity of species of the genus Bacillus: Qualitative studies with Bacillus subtilis and Bacillus pumilus in relation to the softening op olives and pickles. J Food Sci, 18(1-6): 57-69. 
Ogawa, A., Sawada, K., Saito, K., Hakamada, Y., Sumitomo, N., et al. (2000) A new high-alkaline and high-molecular-weight pectate lyase from a Bacillus isolate: enzymatic properties and cloning of the gene for the enzyme. Biosci Biotechnol Biochem, 64(6): 1133-1141.

Ouattara, H. G., Reverchon, S., Niamke, S. L., \&t Nasser, W. (2011) Molecular identification and pectate lyase production by Bacillus strains involved in cocoa fermentation. Food microbiol, 28(1): 1-8.

Oumer, O. J., \&t Abate, D. (2017) Characterization of Pectinase from Bacillus subtilis Strain Btk 27 and Its Potential Application in Removal of Mucilage from Coffee Beans. Enzyme Res, 2017.

Pedrolli, D. B., \&t Carmona, E. C. (2014) Purification and characterization of a unique pectin lyase from Aspergillus giganteus able to release unsaturated monogalacturonate during pectin degradation. Enzyme res, 2014.

Pedrolli, D. B., Monteiro, A. C., Gomes, E., \& Carmona, E. C. (2009) Pectin and pectinases: production, characterization and industrial application of microbial pectinolytic enzymes. Open Biotechnol J, 3: 9-18.

Pitkanen, K., Heikinheimo, R., \&t Pakkanen, R. (1992) Purification and characterization of Erwinia chrysanthemi B374 pectin methylesterase produced by Bacillus subtilis. Enzyme Microb Technol, 14(10): 832-836.

Potter, L. F., \& McCoy, E. (1955) The fermentation of pectin and pectic acid by Bacillus polymyxa. J Bacteriol, 70(6): 656662.

Prathyusha, K., \&t Suneetha, V. (2011) Bacterial pectinases and their potent biotechnological application in fruit processing/ juice production industry: a review. J Phytol, 3(6).

Priest, F. G. (1977) Extracellular enzyme synthesis in the genus Bacillus. Bacteriol Rev, 41(3): 711-753.

Qureshi, A. S., Bhutto, M. A., Chisti, Y., Khushk, I., Dahot, M. U., et al. (2012) Production of pectinase by Bacillus subtilis EFRL 01 in a date syrup medium. African J Biotechnol, 11(62): 12563-12570.

Ramirez-Tapias, Y. A., Rivero, C. W., Britos, C. N., \&t Trelles, J. A. (2015) Alkaline and thermostable polygalacturonase from Streptomyces halstedii ATCC 10897 with applications in waste waters. Biocatal Agric Biotechnol, 4(2): 221-228.

Rastegari, B., \& Karbalaei, H. H. R. (2014) Isolation and Partial Characterization of a Bacterial Thermostable Polymethyl Galacturonase from a Newly Isolated Bacillus sp strain BR1390. Iranian J Biotechnol, 12(4): 41-46.

Rehman, H. U., Aman, A., Nawaz, M. A., \&t Ul Qader, S. A. (2015) Characterization of pectin degrading polygalacturonase produced by Bacillus licheniformis KIBGE-IB21. Food Hydrocoll, 43: 819-824.

Rehman, H. U., Nawaz, M. A., Aman, A., Baloch, A. H., \& Qader, S. A. U. (2014) Immobilization of pectinase from Bacillus licheniformis KIBGE-IB21 on chitosan beads for continuous degradation of pectin polymers. Biocatal Agric Biotechnol, 3(4): 282-287.
Rehman, H. U., Qader, S. A., \&t Aman, A. (2012) Polygalacturonase: production of pectin depolymerising enzyme from Bacillus licheniformis KIBGE IB-21. Carbohydr Polym, 90(1): 387-391.

Remoroza, C., Wagenknecht, M., Buchholt, H. C., Moerschbacher, B. M., Gruppen, H., et al. (2015) Mode of action of Bacillus licheniformis pectin methylesterase on highly methylesterified and acetylated pectins. Carbohydr Polym, 115: 540550.

Remoroza, C., Wagenknecht, M., Gu, F., Buchholt, H. C., Moerschbacher, B. M., et al. (2014) A Bacillus licheniformis pectin acetylesterase is specific for homogalacturonans acetylated at 0-3. Carbohydr Polym, 107: 85-93.

Roosdiana, A., Prasetyawan, S., Mahdi, C., \&t Sutrisno, S. (2013) Production and characterization of Bacillus firmus pectinase. JPACR, 2(1): 35-41.

Sakai, T., Ikemoto, K., \&t Ozaki, Y. (1989) Purification, Crystallization, and Characterization of a Novel Protopectinase from Bacillus subtilis. Agric Biol Chem, 53(5): 1213-1223.

Sakai, T., \& Sakamoto, T. (1990) Purification and some properties of a Protopectin-solubilizing enzyme that has potent activity on Sugar-beet Protopectin. Agric Biol Chem, 54(4): 879-889.

Sakai, T., Sakamoto, T., Hallaert, J., \&t Vandamme, E. J. (1993) Pectin, Pectinase, and Protopectinase: Production, Properties, and Applications. Adv Appl Microbiol, 39: 213-294.

Sakamoto, T., Hours, R. A., \&t Sakai, T. (1994) Purification, characterization, and production of two pectic transeliminases with protopectinase activity from Bacillus subtilis. Biosci Biotechnol Biochem, 58(2): 353-358.

Sakamoto, T., Kawasaki, H., \& Sakai, T. (1996) Molecular cloning and nucleotide sequence of the gene encoding phosphateinducible pectin lyase of Bacillus subtilis. FEBS lett, 398(2-3): 269-273.

Satyanarayana.T, Sharma D.C , Rao J.L.U.M , Ezhilvannan. M, Et S, B. M. a. A. (2005). Potential applications of enzymes produced by the species of Bacillus and Geobacillus .: IK International Pvt Ltd.

Sawada, K., Suzumatsu, A., Kobayashi, T., \&t Ito, S. (2001) Molecular cloning and sequencing of the gene encoding an exopolygalacturonase of a Bacillus isolate and properties of its recombinant enzyme. Biochim Biophys Acta, 1568(2): 162170.

Schallmey, M., Singh, A., \& Ward, O. P. (2004) Developments in the use of Bacillus species for industrial production. Canadian J Microbiol, 50(1): 1-17.

Sharma, D. C., \&t Satyanarayana, T. (2006) A marked enhancement in the production of a highly alkaline and thermostable pectinase by Bacillus pumilus dcsr 1 in submerged fermentation by using statistical methods. Bioresour Technol, 97(5): 727-733.

Sharma, N., Rathore, M., \&t Sharma, M. (2013) Microbial pectinase: sources, characterization and applications. Rev Environ Sci Biotechnol 12(1): 45-60. 
Soares, M. M. C. N., Da Silva, R., Carmona, E. C., \&t Gomes, E. (2001) Pectinolytic enzyme production by Bacillus species and their potential application on juice extraction. World J Microbiol Biotechnol, 17(1): 79-82.

Soares, M. M. C. N., da Silva, R., \&t Gomes, E. (1999) Screening of bacterial strains for pectinolytic activity: Characterization of the polygalacturonase produced by Bacillus sp. Revista De Microbiologia, 30(4): 299-303.

Sohail, M., \& Latif, Z. (2016) Phylogenetic Analysis of Polygalacturonase producing Bacillus and Pseudomonas isolated from plant waste material. Jundishapur J Microbiol, 9(1): e28594.

Stein, T. (2005) Bacillus subtilis antibiotics: structures, syntheses and specific functions. Mol Microbiol, 56(4): 845-857.

Takao, M., Nakaniwa, T., Yoshikawa, K., Terashita, T., \& Sakai, T. (2000) Purification and characterization of thermostable pectate lyase with protopectinase activity from thermophilic Bacillus sp. TS 47. Biosci Biotechnol Biochem, 64(11): 23602367.

Tepe, O., \&t Dursun, A. Y. (2014) Exo-pectinase production by Bacillus pumilus using different agricultural wastes and optimizing of medium components using response surface methodology. Environ Sci Pollut Res Int, 21(16): 9911-9920.

Torimiro, N., \&t Okonji, R. (2013) A comparative study of pectinolytic enzyme production by Bacillus species. African J Biotechnol, 12(46): 6498-6503.
Wang, Q., Fan, X. R., Hua, Z. Z., \&t Chen, J. (2007) Optimizing bioscouring condition of cotton knitted fabrics with an alkaline pectinase from Bacillus subtilis WSHB04-02 by using response surface methodology. Biochem Eng J, 34(2): 107113.

Whitaker, J. R. (1990). Microbial pectolytic enzymes. In W. M. Fogarty \& C. T. Kelly (Eds.), Microbial enzymes and biotechnology (2 ed., pp. 133-176). Netherlands: Springer.

Yu, P., \& Xu, C. (2018) Production optimization, purification and characterization of a heat-tolerant acidic pectinase from Bacillus sp. ZJ1407. Int J Biol Macromol, 108: 972-980.

Yu, P., Zhang, Y., \&t Gu, D. (2017) Production optimization of a heat-tolerant alkaline pectinase from Bacillus subtilis ZGL14 and its purification and characterization. Bioengineered: $1-11$.

Zhang, C. J., Yao, J., Zhou, C., Mao, L. W., Zhang, G. M., et al. (2013) The alkaline pectate lyase PEL168 of Bacillus subtilis heterologously expressed in Pichia pastoris is more stable and efficient for degumming ramie fiber. Bmc Biotechnol, 13(1): 26.

Zou, M., Guo, F., Li, X., Zhao, J., \&t Qu, Y. (2014) Enhancing production of alkaline polygalacturonate lyase from Bacillus subtilis by fed-batch fermentation. PLoS One, 9(3): e90392. 